\title{
Rock Mass Characterization and Support Design for Underground Additional Surge Pool Cavern-A Case Study, India
}

\author{
Ajay Kumar Naithani*, Laishram Gopeshwor Singh, Prasnna Jain \\ National Institute of Rock Mechanics, Bengaluru, India \\ Email: *ajay_naithani@hotmail.com
}

How to cite this paper: Naithani, A.K., Singh, L.G. and Jain, P. (2017) Rock Mass Characterization and Support Design for Underground Additional Surge Pool Cavern-A Case Study, India. Geomaterials, 7, 64-82.

https://doi.org/10.4236/gm.2017.72006

Received: March 1, 2017

Accepted: April 11, 2017

Published: April 14, 2017

Copyright ( $\odot 2017$ by authors and Scientific Research Publishing Inc. This work is licensed under the Creative Commons Attribution International License (CC BY 4.0).

http://creativecommons.org/licenses/by/4.0/

\begin{abstract}
For better rock mass characterization and support design, 3D engineering geological mapping was carried for the heading portion of the under construction $200.00 \mathrm{~m}$ long, $68.75 \mathrm{~m}$ high and $20.20 \mathrm{~m}$ wide underground additional surge pool cavern of a Pranahitha-Chevella Sujala Sravanthi lift irrigation scheme package 8, India. To study cavern behavior, 3D geologic mapping of heading portion is very important for large cavern for predicting geologic conditions in benching down up to invert level, planning support system, selecting inclination for best location of supplemental rock bolt and choosing strategic locations for various types of instrumentation. The assessment of Tunnel Quality Index " $Q$ " and Geomechanics classification for the granitic rock mass was done based on the information available of the rock joints and their nature and 3D geological logging. Hoek-Brown parameters were also determined by the statistical analysis of the results of a set of triaxial tests on core samples. On basis of geological characteristics and NMT $Q$-system chart, support system is recommended which includes rock bolt, steel fibre reinforced shotcrete and grouting. To evaluate the efficacy of the proposed support system, the capacity of support system is determined.
\end{abstract}

\section{Keywords}

Engineering Geology, Underground Cavern, Support System, Rock Bolt, Shotcrete

\section{Introduction}

Analytical, observational, and empirical are the main design approach for excavations in rock. In this paper, empirical approach for support design of additional surge pool cavern of a Pranahitha-Chevella Sujala Sravanthi lift irrigation 
scheme package 8 (PCSSLIS-P8) is discussed. Rock mass classifications as practiced in civil and mining engineering form an integral part of the empirical design methods, which is the most predominant design approach [1]. The main objectives of the rock mass classifications are to identify the most significant parameters influencing the behavior of a rock mass, divide area into rock mass classes of varying quality and provide quantitative data for engineering design purpose. Rock mass classifications have played an important role in estimating the strength and deformability of rock masses and in assessing the stability of rock slopes. They were also shown to have special uses for serving as an index to rock rippability, dredgeability, excavatability, cuttability, and cavability. For underground excavation, stable empirical approaches are developed based on the evaluation of a large number of case studies.

The major components of the PCSSLIS-P8 are: $4.133 \mathrm{~km}$ long and $10.00 \mathrm{~m}$ finished diameter " $D$ " shaped twin tunnels, old surge pool $(350 \mathrm{~m}$ long $\times 20 \mathrm{~m}$ width $\times 54 \mathrm{~m}$ height), $58 \mathrm{~m}$ long five numbers of draft tube tunnels, one pump house ( $215 \mathrm{~m}$ long $\times 25 \mathrm{~m}$ width $\times 54 \mathrm{~m}$ height) and five numbers, $50 \mathrm{~m}$ long horizontal and $150 \mathrm{~m}$ vertical shaft having $5.0 \mathrm{~m}$ finished diameter pressure mains, $80 \mathrm{~m}$ long delivery cistern and $5.85 \mathrm{~km}$ long gravity canal from delivery cistern to join flood flow canal. Lift height is about $126 \mathrm{~m}$ and five numbers of pump will be installed in the pump house cavity having $130 \mathrm{MW}$ capacities each. The reengineering of the project was done and because of this additional surge pool is being constructed for increased discharge from 419 to 624 cumecs. Summary of input data of additional surge pool cavern used for support design as provided by sponsoring agency are given in Table 1 . Sufficient lateral rock

Table 1. Summary of input data.

\begin{tabular}{lcc}
\hline 1 & Length of surge pool with approach for ventilation & $200+25 \mathrm{~m}$ \\
2 & Excavated width of cavern $(B)$ & $20.20 \mathrm{~m}$ \\
3 & Clear width of cavern & $20.00 \mathrm{~m}$ \\
4 & Crown level & $250.25 \mathrm{~m}$ \\
5 & Spring level & $240.00 \mathrm{~m}$ \\
6 & Surge pit level & $181.50 \mathrm{~m}$ \\
7 & Height of surge pit wall & $58.50 \mathrm{~m}$ \\
8 & Height of overburden above crown $(H)$ & $70.75($ average $)$ \\
9 & Ground levels maximum and minimum above crown & $321 \mathrm{~m} \mathrm{and} \mathrm{319} \mathrm{m}$ \\
10 & Rise of arc & $10.25 \mathrm{~m}$ \\
11 & Unit weight of rock $(\gamma)$ & $2.60 \mathrm{t} / \mathrm{m}^{3}$ \\
12 & Average spacing of joints & $0.750 \mathrm{~m}$ \\
13 & Maximum upsurge level & $239.9 \mathrm{~m}$ \\
14 & Minimum downsurge level & $214.8 \mathrm{~m}$ \\
15 & Thickness of concrete lined bottom portion & $300 \mathrm{~mm}$ \\
16 & Rock ledge between old and new surge pool & $100 \mathrm{~m}$ \\
\hline
\end{tabular}


cover is available, and the vertical cover is more than $1 \mathrm{D}$ i.e. $>70 \mathrm{~m}$ above the surge pool.

For the underground cavern rock mass characterization was done based on $3 \mathrm{D}$ geologic mapping and laboratory test results. On basis of geological characteristics and NMT $Q$-system chart, support system is recommended and its efficacy is evaluated.

\section{3D Geological Mapping}

3D engineering geological mapping was done in 1:100 scale so that closely spaced geological discontinuities can be mapped (Figure 1). Geologic logging provides a permanent record of all geologic defects exposed on the walls and crown of an underground excavation. Rock type mapped was pink granite belongs to the Peninsular Gneissic Complex of Archaean age [2] [3]. Granite was coarse grained, hard and jointed in nature. The granite was generally fresh in nature. It was interpreted that same rock will be present during the benching of additional surge pool up to its invert level.

The details of the joint characteristics are given in Table 2. Joints are generally

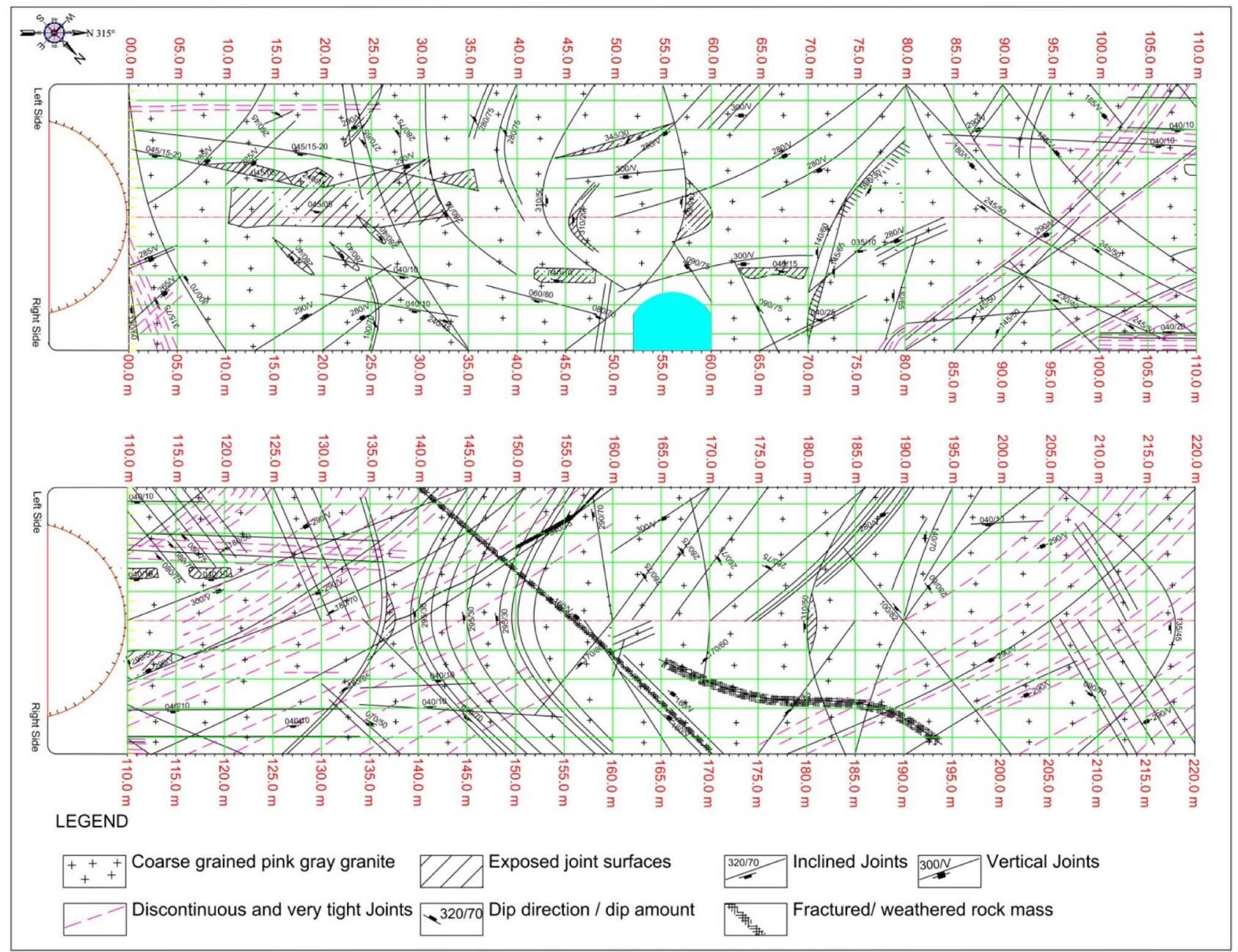

Figure 1. 3D Geological map of the heading portion. 
Table 2. Joint sets recorded in coarse grained pink granite.

\begin{tabular}{|c|c|c|c|c|c|c|c|}
\hline Joint sets & Azimuth/Dip Amount & Spacing $(\mathrm{cm})$ & Strike length (m) & Roughness & Aperture (mm) & Infilling & GW \\
\hline $\mathrm{J} 1$ & $280-300 / \mathrm{V}$ & $30-150$ & $>20$ & Smooth, planar & Tight & Fresh/clay coated & Dry \\
\hline $\mathrm{J} 2$ & $035-045 / 10-25$ & $30-100$ & $>20$ & Smooth, planar & Tight & Fresh/clay coated & Dry \\
\hline $\mathrm{J} 3$ & $280-310 / 65-75$ & $60-200$ & $>20$ & Smooth, planar & Tight & Fresh/clay coated & Dry \\
\hline $\mathrm{J} 4$ & $280-300 / 30-50$ & $75-200$ & $>20$ & Smooth, planar & Tight & $\begin{array}{l}\text { Fresh/clay coated } \\
\qquad(2-4 \mathrm{~mm})\end{array}$ & Dry \\
\hline $\mathrm{J} 5$ & $130-145 / 50-70$ & $>100$ & $>20$ & Smooth, planar & Tight to $3 \mathrm{~mm}$ & $\begin{array}{l}\text { Fresh to } 3-5 \mathrm{~mm} \text { clay } \\
\text { filling }\end{array}$ & Dry \\
\hline J6 & $240-260 / 40-50$ & $>100$ & $>15$ & $\begin{array}{l}\text { Smooth, planar } \\
\text { /undulating }\end{array}$ & Tight to $3 \mathrm{~mm}$ & $\begin{array}{c}\text { Fresh to } 3-5 \mathrm{~mm} \\
\text { slightly alter }\end{array}$ & Dry \\
\hline $\mathrm{J} 7$ & $080-100 / 70-80$ & $>100$ & $>10$ & Smooth, planar & Tight & Fresh & Dry \\
\hline $\mathrm{J} 8$ & $070-080 / 50$ & $>100$ & $>10$ & Smooth, planar & Tight & Fresh & Dry \\
\hline J9 & $170-185 / 50-70$ & $>100$ & $>10$ & Smooth, planar & Tight & Fresh & Dry \\
\hline JR1 & $330-345 / 30-50$ & $>100$ & $<10$ & Smooth, planar & Tight & Fresh/clay coated & Dry \\
\hline JR2 & $300-310 / 20-30$ & $>100$ & $<10$ & Smooth, planar & Tight & Fresh & Dry \\
\hline JR3 & $160-180 / \mathrm{V}$ & $>100$ & $>10$ & Smooth, planar & Tight & $\begin{array}{c}\text { Slightly altered joint } \\
\text { walls }\end{array}$ & Dry \\
\hline JR4 & $240 / 15$ & $>100$ & $>10$ & Smooth, planar & Tight & Fresh & Dry \\
\hline JR5 & $060 / 80$ & $>100$ & $>10$ & Smooth, planar & Tight & Fresh & Dry \\
\hline JR6 & $340 / 75$ & $>100$ & $>10$ & Smooth, planar & Tight & Fresh & Dry \\
\hline
\end{tabular}

Notes: GW-Groundwater, JR—Random joint, V-Vertical.

continuous and persistent, smooth-planar with unaltered to slightly altered joint walls. Staining has been recorded along the joint surfaces where the joints are tight and where opening is up to $3.0 \mathrm{~mm}$, clay filling has been recorded. In general, the rock mass is characterized by dry condition or minor inflow i.e. $<5.0$ $1 / \mathrm{min}$.

\section{Laboratory Testing}

Selected rock core samples were tested for their physico-mechanical properties and test results as provided by MEIL are summarized in Table 3. The compressive strength of core specimens is ranging from 132 to $238 \mathrm{MPa}$ and density varies between 2645 to $2695 \mathrm{~kg} / \mathrm{m}^{3}$. According to strength classification criterion for rock substance, the rocks are of very high strength [4] and density of material is high.

\section{Rock Mass Classification}

\subsection{Tunnelling Quality Index $(Q)$}

The Q-system was developed at NGI between 1971 and 1974 on the basis of approximately 200 case histories of tunnels and caverns [5]. They presented a useful correlation between the amount and type of permanent support and the $Q$ with respect to tunnel stability. There has been a significant advance within 
Table 3. Results of lab tests to rock samples.

\begin{tabular}{|c|c|c|c|c|c|c|c|c|}
\hline Rock Type & $\begin{array}{l}\text { Elevation } \\
(\mathrm{m})\end{array}$ & $\begin{array}{l}\text { Density } \\
\left(\mathrm{kg} / \mathrm{m}^{3}\right)\end{array}$ & $\begin{array}{l}\text { Uniaxial Compressive } \\
\text { Strength-Dry (MPa) }\end{array}$ & $\begin{array}{c}\text { Tensile } \\
\text { Strength (MPa) }\end{array}$ & $\begin{array}{c}\text { Modulus of } \\
\text { Elasticity (GPa) }\end{array}$ & $\begin{array}{l}\text { Poisson's } \\
\text { Ratio }\end{array}$ & $\begin{array}{c}\text { Cohesion } \\
\text { (PMa) }\end{array}$ & $\begin{array}{c}\text { Friction } \\
\text { Angle }\end{array}$ \\
\hline Pink granite & 249.50 & 2695 & 212 & 11.50 & 74.30 & - & 47.81 & 46.09 \\
\hline Pink granite & 255.50 & - & - & $11.10-12.90$ & - & - & - & - \\
\hline Pink granite & 260.00 & - & - & 9.50 & - & - & - & - \\
\hline Pink granite & 261.50 & 2645 & 180 & - & 105.77 & - & 44.22 & 50.03 \\
\hline Pink granite & 266.00 & 2690 & - & 10.80 & - & - & 45.38 & 49.24 \\
\hline Pink granite & 273.50 & 2653 & 238 & 12.70 & 64.70 & - & 47.75 & 54.49 \\
\hline Pink granite & 274.00 & 2695 & 191 & 11.00 & 71.36 & 0.25 & 38.14 & 47.37 \\
\hline Pink granite & 285.00 & 2682 & 138 & - & 79.79 & - & - & - \\
\hline
\end{tabular}

support philosophy and technology in underground excavations since the introduction of the Q-system in 1974. After its introduction in 1974, two revisions of the support chart have been carried out. On the basis of 1050 examples mainly from Norwegian underground excavations an extensive updating was done in 1993 [6]. Based on more than 900 new examples from underground excavations in Norway, Switzerland and India, an updating was made in 2002. This update also included analytical research with respect to the thickness, spacing and reinforcement of reinforced ribs of sprayed concrete as a function of the load and the mass quality [7].

The $Q$-value gives a description of the rock mass stability of an underground opening in jointed rock masses. High $Q$-values indicates good stability and low values means poor stability. The numerical value of the index $Q$ varies on a logarithmic scale from 0.001 to a maximum of 1000 and is defined by six parameters (Equation (1)). $Q$-value 0.001 is generally for exceptionally poor quality squeezing ground, while 1000 is for exceptionally good quality rock which is practically unjointed [5].

$$
Q=\frac{\mathrm{RQD}}{\mathrm{J}_{\mathrm{n}}} \times \frac{J_{r}}{J_{a}} \times \frac{J_{w}}{\mathrm{SRF}}
$$

where RQD is Rock Quality Designation (degree of jointing), $J_{n}$ is Number of joint sets, $J_{r}$ is Joint roughness number, $J_{a}$ is Joint alteration number, $J_{w}$ is Joint water reduction factor and SRF is Stress Reduction Factor

For the heading portion of additional surge pool the individual parameters were determined during geological mapping using tables that give numerical values to be assigned to a described situation. For the calculation of $Q$-values all the discontinuities per $5 \mathrm{~m}$ length and circumference were taken into consideration. An average piece size or block size can be determined using the same data i.e. discontinuities per $5 \mathrm{~m}$ length and circumference. The assessment of $Q$-values for the granitic rock mass, based on the information available of the rock joints and their nature and 3D geological logging, is tabulated in Table 4. The grade of rock mass based on the rock joints characteristics has the $Q$-values varying from 4.17 to 16.33 , and it comes under fair to good rock mass category. 
Table 4. Q-values recorded from the heading portion of the additional surge pool.

\begin{tabular}{|c|c|c|c|c|c|c|c|c|c|}
\hline \multirow{2}{*}{$\begin{array}{l}\text { Chainage } \\
\text { (m) }\end{array}$} & \multirow{2}{*}{ Rock Type } & \multirow{2}{*}{$\begin{array}{l}\text { RQD } \\
(\%)\end{array}$} & \multirow{2}{*}{$J_{n}$} & \multirow{2}{*}{$J_{r}$} & \multirow{2}{*}{$J_{a}$} & \multirow{2}{*}{$J_{w}$} & \multirow{2}{*}{ SRF } & \multicolumn{2}{|l|}{ Q } \\
\hline & & & & & & & & Value & Class \\
\hline $0-20$ & $\begin{array}{l}\text { Coarse grained pink } \\
\text { granite }\end{array}$ & $92-98$ & 2 to 3 & $\begin{array}{l}\text { Smooth } \\
\text { planar }\end{array}$ & $\begin{array}{l}\text { Slightly altered to } \\
\text { unaltered joint wall }\end{array}$ & $\begin{array}{l}\text { Minor inflow to dry } \\
\text { excavation }\end{array}$ & $\begin{array}{l}\text { Medium } \\
\text { stress }\end{array}$ & 10.22 to 16.33 & Good \\
\hline $20-30$ & $\begin{array}{l}\text { Coarse grained pink } \\
\text { granite }\end{array}$ & 95 & $2+\mathrm{R}$ & $\begin{array}{l}\text { Smooth } \\
\text { planar }\end{array}$ & $\begin{array}{l}\text { Slightly altered } \\
\text { joint walls }\end{array}$ & Minor inflow & $\begin{array}{l}\text { Medium } \\
\text { stress }\end{array}$ & 7.92 & Fair \\
\hline $30-65$ & $\begin{array}{c}\text { Coarse grained pink } \\
\text { granite }\end{array}$ & $88-99$ & 2 to 3 & $\begin{array}{l}\text { Smooth } \\
\text { planar }\end{array}$ & $\begin{array}{l}\text { Slightly altered to } \\
\text { unaltered joint wall }\end{array}$ & Dry excavation & $\begin{array}{l}\text { Medium } \\
\text { stress }\end{array}$ & $10.89-15.33$ & Good \\
\hline $65-105$ & $\begin{array}{l}\text { Coarse grained pink } \\
\text { granite }\end{array}$ & $82-95$ & $2+\mathrm{R}$ to 3 & $\begin{array}{l}\text { Smooth } \\
\text { planar }\end{array}$ & $\begin{array}{l}\text { Slightly altered } \\
\text { joint walls }\end{array}$ & $\begin{array}{l}\text { Minor inflow to dry } \\
\text { excavation }\end{array}$ & $\begin{array}{l}\text { Medium } \\
\text { stress }\end{array}$ & $4.72-7.92$ & Fair \\
\hline $105-125$ & $\begin{array}{l}\text { Coarse grained pink } \\
\text { granite }\end{array}$ & $75-95$ & $2+R$ to 3 & $\begin{array}{l}\text { Smooth } \\
\text { planar }\end{array}$ & Unaltered joint wall & $\begin{array}{l}\text { Minor inflow to dry } \\
\text { excavation }\end{array}$ & $\begin{array}{l}\text { Medium } \\
\text { stress }\end{array}$ & $10.56-14.17$ & Good \\
\hline $125-195$ & $\begin{array}{c}\text { Coarse grained pink } \\
\text { granite }\end{array}$ & $75-95$ & $2+\mathrm{R}$ to 3 & $\begin{array}{l}\text { Smooth } \\
\text { planar }\end{array}$ & $\begin{array}{l}\text { Slightly altered } \\
\text { joint walls }\end{array}$ & $\begin{array}{l}\text { Minor inflow to dry } \\
\text { excavation }\end{array}$ & $\begin{array}{l}\text { Medium } \\
\text { stress }\end{array}$ & $4.17-7.92$ & Fair \\
\hline $195-210$ & $\begin{array}{c}\text { Coarse grained pink } \\
\text { granite }\end{array}$ & $95-98$ & $2+\mathrm{R}$ & $\begin{array}{l}\text { Smooth } \\
\text { planar }\end{array}$ & Unaltered joint wall & Dry excavation & $\begin{array}{l}\text { Medium } \\
\text { stress }\end{array}$ & $15.83-16.33$ & Good \\
\hline $210-220$ & $\begin{array}{c}\text { Coarse grained pink } \\
\text { granite }\end{array}$ & 95 & $2+R$ & $\begin{array}{l}\text { Smooth } \\
\text { planar }\end{array}$ & $\begin{array}{l}\text { Slightly altered } \\
\text { joint walls }\end{array}$ & Dry excavation & $\begin{array}{l}\text { Medium } \\
\text { stress }\end{array}$ & 7.92 & Fair \\
\hline
\end{tabular}

$\mathrm{RQD}=$ Rock Quality Designation, Jn = Joint Set Number, Jr = Joint Roughness Number, Ja = Joint Alteration Number, Jw = Joint Water Reduction Factor and SRF $=$ Stress Reduction Factor.

Total 59 percent of area comes under fair rock mass category while 41 percent under good rock mass category. The average $Q$-value calculated is 9.58 . The low $Q$-values are because of intersection of more joint sets in the excavated span of 5 $\mathrm{m}$ and joints surface characteristics.

\subsection{Geomechanics Classification}

The Geomechanics Classification, also known as the Rock Mass Rating system, was developed by Bieniawski during 1972-1973 on the basis of 49 case histories [8]. It was modified over the years as more case histories become available and to conform with international standards and procedures [9]. In 1984, 62 coal mining case histories were added and a further 78 tunneling and mining case histories collected by 1987. Last time it was modified in 1989 by Bieniawski amounting to 351 case histories. Since then it is being used in tunnels, chambers, mines, slopes and foundations projects. Most of the applications have been in the field of tunneling. This classification is one of the most commonly used rock mass classification system. This is based on the collection of field data and strength parameter. The six parameters which are used to classify a rock mass using RMR system are: uniaxial compressive strength of rock material (UCS), rock quality designation (RQD), spacing of discontinuities (SD), condition of discontinuities $(\mathrm{CD})$, groundwater conditions $(\mathrm{GW})$ and orientation of discontinuities (OD) (Equation (2)).

$$
\mathrm{RMR}=\mathrm{UCS}+\mathrm{RQD}+\mathrm{SD}+\mathrm{CD}+\mathrm{GW}-\mathrm{OD}
$$

In order to apply the RMR classification, the rock mass has to be divided into 
a number of structural regions such that certain features are more or less uniform within each region. Rock Mass Rating technique has been found to be quite useful due to the ease with which it can be practiced and its effectiveness in interpreting stability and recommending control measures. The RMR classification parameters are easily obtained either from borehole data or underground/ surface mapping [10] [11] [12]. Average stand-up time for an arched roof, cohesion and angle of internal friction, modulus of deformation, allowable bearing pressure, shear strength of rock mass and estimation of support pressure of rock mass may be obtained using RMR. For the heading portion of additional surge pool, RMR values are determined at every $5 \mathrm{~m}$ interval (Table 5 ). The grade of rock mass based on the $3 \mathrm{D}$ geological mapping and strength characteristics, has the RMR values varying from 53 to 71, and it comes under fair to good rock category. The average RMR-value calculated is 62 .

\subsection{Hoek-Brown Parameters}

In order to use the Hoek-Brown criterion for estimating the strength and deformability of jointed rock masses, the value of the Geological Strength Index (GSI) for the rock mass, the uniaxial compressive strength $\left(\sigma_{c i}\right)$ of the intact rock pieces, and the value of Hoek-Brown constant $\left(m_{i}\right)$ for these intact rock pieces have been estimated. Geological Strength Index (GSI) was introduced by Hoek and Brown (1997) to provide a system for estimating the reduction in the rock mass strength for different geological conditions. The GSI can be related to the rock mass rating $(\mathrm{RMR})$ or the modified rock-mass quality index $\left(Q^{\prime}\right)$. Modified rock-mass quality index is defined as (Equation (3)):

$$
Q^{\prime}=\frac{\mathrm{RQD}}{J_{n}} \times \frac{J_{r}}{J_{a}}
$$

where RQD is the rock quality designation, $J_{n}$ is the joint set number, $J_{r}$ is the joint roughness number, $J_{a}$ is the joint alteration number.

Hoek and Brown [13] suggested that GSI can be related to $Q$ and RMR by following equations (Equation (4) and Equation (5)). Bieniawski's RMR classification should be used for estimating GSI values for better rock masses (GSI > 25 ) and should not be used for poor quality rock masses.

Table 5. RMR-values determined at different chainage.

\begin{tabular}{|c|c|c|c|c|c|c|c|c|c|c|c|c|c|}
\hline \multirow{2}{*}{$\begin{array}{l}\text { Chainage } \\
\text { (m) }\end{array}$} & \multirow{2}{*}{$\begin{array}{c}\text { UCS } \\
(\mathrm{MPa})\end{array}$} & \multirow{2}{*}{$\begin{array}{l}\text { RQD } \\
\%\end{array}$} & \multirow{2}{*}{$\begin{array}{l}\text { Spacing } \\
(\mathrm{cm})\end{array}$} & \multicolumn{5}{|c|}{ Condition of Discontinuity } & \multirow{2}{*}{$\begin{array}{l}\text { Ground } \\
\text { water }\end{array}$} & \multicolumn{2}{|c|}{ Adjustment } & \multicolumn{2}{|r|}{ RMR } \\
\hline & & & & $\begin{array}{l}\text { Persistence } \\
\quad(\mathrm{m})\end{array}$ & $\begin{array}{l}\text { Aperture } \\
(\mathrm{mm})\end{array}$ & Roughness & $\begin{array}{l}\text { Infilling } \\
(\mathrm{mm})\end{array}$ & $\begin{array}{c}\text { Weathering } \\
\text { grade }\end{array}$ & & Orientation & Rating & Rating & Description \\
\hline $0-20$ & 212 & $92-98$ & $60-200$ & $>20$ & $<0.1-1.5$ & Smooth & Soft $>5$ & W-I & Damp - dry & Fair & -5 & $66-71$ & Good rock \\
\hline $20-30$ & 191 & 95 & $60-200$ & $>20$ & $1-5$ & Smooth & Soft $>5$ & W-I & Damp & Fair & -5 & 62 & Good rock \\
\hline $30-65$ & 180 & $88-99$ & $60-200$ & $>20$ & $<0.1-1.5$ & Smooth & Soft $>5$ & W-I & Dry & Fair & -5 & $67-71$ & Good rock \\
\hline $65-195$ & $138-180$ & $75-95$ & $\begin{array}{c}20-60 \& \\
60-200\end{array}$ & $>20$ & $\begin{array}{c}<0.1 \& \\
1-5\end{array}$ & Smooth & Soft $>5$ & W-I-WII & Damp - dry & Fair & -5 & $53-65$ & Fair to Good rock \\
\hline $195-220$ & 238 & $95-98$ & $60-200$ & $>20$ & $<0.1-1.5$ & Smooth & Soft $>5$ & W-I & Dry & Fair & -5 & $67-71$ & Good rock \\
\hline
\end{tabular}


Table 6. Rock mass classification of granite.

\begin{tabular}{|c|c|c|c|c|c|c|c|c|c|c|}
\hline \multirow{3}{*}{ Category } & \multicolumn{2}{|c|}{ Q } & \multicolumn{2}{|c|}{ RMR } & \multicolumn{6}{|c|}{ GSI Calculated/Estimated } \\
\hline & \multirow{2}{*}{ Value } & \multirow{2}{*}{ Class } & \multirow{2}{*}{ Value } & \multirow{2}{*}{ Class } & \multicolumn{2}{|c|}{ From Q' } & \multicolumn{2}{|c|}{ From RMR } & \multicolumn{2}{|c|}{ From Hoek-Brown Chart } \\
\hline & & & & & Value & Class & Value & Class & Value & Class \\
\hline Minimum & 4.17 & Fair & 53 & Fair & 56.85 & Good & 48 & Fair & 45 & Fair \\
\hline Maximum & 16.33 & Good & 71 & Good & 69.14 & Good & 66 & Good & 65 & Good \\
\hline Average & 9.58 & Fair & 62 & Good & 64.34 & Good & 57 & Good & 55 & Fair \\
\hline Mean & 11.92 & Good & 63 & Good & 66.30 & Good & 58 & Good & 56 & Good \\
\hline
\end{tabular}

$$
\begin{aligned}
& \mathrm{GSI}=9 \ln Q^{\prime}+44 \\
& \mathrm{GSI}=\mathrm{RMR}_{89}-5
\end{aligned}
$$

For the additional surge pool GSI is calculated from $Q^{\prime}$, RMR and Hoek and Brown [13] chart. Hoek and Brown chart is based on geological description of the rock mass i.e. on the basis of interlocking and joint alteration. Minimum, maximum, average and mean values of $Q$, RMR and GSI are given in Table 6.

The values of $\sigma_{c i}$ and $m_{i}$ were determined by the statistical analysis of the results of a set of triaxial tests on core samples. After obtaining the test results, they were analysed to determine the uniaxial compressive strength $\left(\sigma_{c i}\right)$ of the intact rock pieces, and the value of Hoek-Brown constant $\left(m_{i}\right)$ as described by Hoek and Brown [14]. A spreadsheet for the analysis of triaxial test data is given in Table 7.

For each sample the uniaxial compressive strength $\left(\sigma_{c i}\right)$, the constant $\left(m_{i}\right)$ and coefficient of determination $\left(r^{2}\right)$ are calculated from Equations (6)-(8) respectively and values are given in Table 8. The Hoek-Brown parameters that describe the rock mass strength characteristics can be derived from GSI (Equation (9)).

$$
\begin{aligned}
& \sigma_{c i}^{2}=\frac{\sum y}{n}-\left[\frac{\sum x y-\left(\sum x \sum y / n\right)}{\sum x^{2}-\left(\left(\sum x\right)^{2} / n\right)}\right] \frac{\sum x}{n} \\
& m_{i}=\frac{1}{\sigma_{c i}}\left[\frac{\sum x y-\left(\sum x \sum y / n\right)}{\sum x^{2}-\left(\left(\sum x\right)^{2} / n\right)}\right] \\
& r^{2}=\frac{\left[\sum x y-\left(\sum x \sum \frac{y}{n}\right)\right]^{2}}{\left[\sum x^{2}-\frac{\left(\sum x\right)^{2}}{n}\right]\left[\frac{\sum y^{2}-\left(\sum y\right)^{2}}{n}\right]} \\
& m_{b}=m_{i} e\left\{\frac{(\mathrm{GSI}-100)}{9}\right\}
\end{aligned}
$$

where $m_{b}$ is the value of the Hoek-Brown constant $m$ for the rock mass and mi is the Hoek-Brown constant for the intact rock. 
Hoek-Brown constants " $s$ " and " $a$ " are depend upon the rock mass characteristics. For GSI > 25, i.e. rock masses of good to reasonable quality, the original Hoek-Brown criterion is applied with (Equation (10) and Equation (11)):

Table 7. Spreadsheet for the calculation of $\sigma_{\mathrm{ci}}$ and mi from triaxial test data.

\begin{tabular}{|c|c|c|c|c|c|}
\hline \multicolumn{6}{|c|}{ Rock sample from elevation $249.50 \mathrm{~m}$} \\
\hline$X\left(\sigma_{3}\right)$ & $\sigma_{1}$ & $y\left(\sigma_{1}-\sigma_{3}\right)^{2}$ & $x y$ & $x^{2}$ & $y^{2}$ \\
\hline 10 & 297 & 82,369 & 823,690 & 100 & $6,784,652,161$ \\
\hline 20 & 363 & 117,649 & $2,352,980$ & 400 & $13,841,287,201$ \\
\hline 30 & 423 & 154,449 & $4,633,470$ & 900 & $23,854,493,601$ \\
\hline 40 & 482 & 195,364 & $7,814,560$ & 1600 & $38,167,092,496$ \\
\hline 100 & 1565 & 549,831 & $15,624,700$ & 3000 & $82,647,525,459$ \\
\hline $\operatorname{Sum} x$ & & Sum $y$ & Sum $x y$ & $\operatorname{Sum} x^{2}$ & $\operatorname{Sum} y^{2}$ \\
\hline \multicolumn{6}{|c|}{ Elevation $261.50 \mathrm{~m}$} \\
\hline 10 & 313 & 91,809 & 918,090 & 100 & $8,428,892,481$ \\
\hline 20 & 402 & 145,924 & $2,918,480$ & 400 & $21,293,813,776$ \\
\hline 30 & 473 & 196,249 & $5,887,470$ & 900 & $38,513,670,001$ \\
\hline 40 & 541 & 251,001 & $10,040,040$ & 1600 & $63,001,502,001$ \\
\hline 100 & 1729 & 684,983 & $19,764,080$ & 3000 & $131,237,878,259$ \\
\hline $\operatorname{Sum} x$ & & Sumy & Sum $x y$ & $\operatorname{Sum} x^{2}$ & $\operatorname{Sum} y^{2}$ \\
\hline \multicolumn{6}{|c|}{ Elevation $266.00 \mathrm{~m}$} \\
\hline 10 & 310 & 90,000 & 900,000 & 100 & $8,100,000,000$ \\
\hline 20 & 396 & 141,376 & $2,827,520$ & 400 & $19,987,173,376$ \\
\hline 30 & 467 & 190,969 & $5,729,070$ & 900 & $36,469,158,961$ \\
\hline 40 & 528 & 238,144 & $9,525,760$ & 1600 & $56,712,564,736$ \\
\hline 100 & 1701 & 660,489 & $18,982,350$ & 3000 & $121,268,897,073$ \\
\hline $\operatorname{Sum} x$ & & Sumy & Sum $x y$ & $\operatorname{Sum} x^{2}$ & Sum $y^{2}$ \\
\hline \multicolumn{6}{|c|}{ Elevation $273.50 \mathrm{~m}$} \\
\hline 10 & 388 & 142,884 & $1,428,840$ & 100 & $20,415,837,456$ \\
\hline 20 & 501 & 231,361 & $4,627,220$ & 400 & $53,527,912,321$ \\
\hline 30 & 599 & 323,761 & $9,712,830$ & 900 & $104,821,185,121$ \\
\hline 40 & 680 & 409,600 & $16,384,000$ & 1600 & $167,772,160,000$ \\
\hline 100 & 2168 & $1,107,606$ & $32,152,890$ & 3000 & $346,537,094,898$ \\
\hline $\operatorname{Sum} x$ & & Sumy & Sum $x y$ & $\operatorname{Sum} x^{2}$ & $\operatorname{Sum} y^{2}$ \\
\hline \multicolumn{6}{|c|}{ Elevation $274.00 \mathrm{~m}$} \\
\hline 10 & 259 & 62,001 & 620,010 & 100 & $3,844,124,001$ \\
\hline 20 & 329 & 95,481 & $1,909,620$ & 400 & $9,116,621,361$ \\
\hline 30 & 393 & 131,769 & $3,953,070$ & 900 & $17,363,069,361$ \\
\hline 40 & 457 & 173,889 & $6,955,560$ & 1600 & $30,237,384,321$ \\
\hline 100 & 1438 & 463,140 & $13,438,260$ & 3000 & $60,561,199,044$ \\
\hline $\operatorname{Sum} x$ & & Sumy & Sum $x y$ & $\operatorname{Sum} x^{2}$ & Sum $y^{2}$ \\
\hline
\end{tabular}


Table 8. Rock mass properties for granite.

\begin{tabular}{cccccc}
\hline Rock Type & $\begin{array}{c}\text { Elevation } \\
(\mathrm{m})\end{array}$ & $\begin{array}{c}\text { Uniaxial } \\
\text { Compressive } \\
\text { Strength }\left(\sigma_{c i}\right)\end{array}$ & $\begin{array}{c}\text { Constant } \\
\left(m_{i}\right)\end{array}$ & $\begin{array}{c}\text { Coefficient of } \\
\text { determination } \\
\left(r^{2}\right)\end{array}$ & $\begin{array}{c}\text { Constant } \\
\left(m_{b}\right)\end{array}$ \\
\hline Pink granite & 249.50 & 208.59 & 18.02 & 0.9 & 3.64 \\
Pink granite & 261.50 & 198.17 & 26.64 & 0.9 & 5.38 \\
Pink granite & 266.00 & 204.00 & 24.22 & 0.9 & 4.89 \\
Pink granite & 273.50 & 231.87 & 38.49 & 0.9 & 7.70 \\
Pink granite & 274.00 & 150.99 & 24.63 & 0.9 & 4.97 \\
\hline & & $S=e\left\{\frac{(\mathrm{GSI}-100)}{9}\right\}$ & &
\end{tabular}

and

$$
a=0.5
$$

The rock mass strength can be characterized by a GSI value of 55 (fair category), which was used to establish the parameters $\left(m_{b}, s\right.$, $a$ etc.) required for the Hoek-Brown failure criterion. The constants " $s$ " and " $a$ " calculated are 0.0067 and 0.5 respectively. For average/fair category rock masses Hoek and Brown [13] assumed that post failure deformation occurs at a constant stress level, defined by the compressive strength of the broken rock mass. The reduction of the rock mass strength from the in situ to the broken state corresponds to the strain softening behaviour. Martin and Maybee [15] assumed that the failed rock behaves as a cohesionless frictional material. These values can be used for modelling because in the rock masses there are a sufficient number of closely spaced discontinuities with almost similar surface characteristics.

\section{Estimation of Support Pressure and Ground Squeezing Condition}

The rock mass quality $(Q)$ is related with the ultimate support pressure requirement. An empirical equation relating rock mass quality $Q$ and permanent support pressure was given by Barton et al. [5] which based on case records (Equation (12)). In this equation importance is given to joint roughness number. Better qualities of rock mass have their improved $Q$ values from the dilatent property of interlocked non-planar rock joints, while the poorer qualities are dominated by more or less non-dilatent clay filled joints [5]. An improved empirical fit (Equation (13)) by incorporating number of joint sets $\left(J_{n}\right)$ in Equation (12) is further suggested by Barton et al. [5]. When rock mass is intersected by three joint sets $\left(J_{n}=9\right.$ ) Equation (12) and Equation (13) will give an identical estimate of roof support pressure. When there are less than three joint sets Equation (13) will give a lower estimate of support pressure than Equation (12), and a higher estimate when there are more than three joint sets. When the number of joint sets falls below three, the degree of freedom for block movement is greatly 
reduced since three joint sets or two plus random is the limiting case for three-dimensional rock blocks. In those equations size of opening does not figure in the support pressure prediction. Singh et al. [16] also studied the effect of tunnel size, span ranging from 2 to $22 \mathrm{~m}$ on support pressure and inferred that they are independent.

In this study roof support and wall support pressure was estimated as per Equations ((14) and (15)), which is applicable for the non-squeezing ground condition [16] [17]. Grimstad and Barton [6] also agreed on the overburden correction factor from Equation (13).

$$
\begin{gathered}
P_{\text {roof }}=\frac{2.0}{J_{r}} Q^{-1 / 3} \\
P_{\text {roof }}=\frac{2 J_{n}^{1 / 2}(Q)^{-1 / 3}}{3 J_{r}} \\
P_{\text {roof }}=\frac{2.0}{J_{r}} Q^{-1 / 3} x f \\
P_{\text {Wall }}=\frac{2.0}{J_{r}} Q_{w}^{-1 / 3} x f
\end{gathered}
$$

where $P_{\text {roof }}$ is permanent/ultimate roof support pressure in $\mathrm{kg} / \mathrm{cm}^{2}$, Where $P_{\text {wall }}$ is ultimate wall support pressure in $\mathrm{kg} / \mathrm{cm}^{2}, J_{r}$ is joint roughness number, $Q$ is rock mass quality, $Q_{w}$ is wall quality/factor equal to $5 Q$ for better qualities rock mass $(Q>10)$ and $2.5 Q$ for intermediate qualities $(0.1<Q<10)$, $J_{n}$ is joint set number and $f$ is correction factor for overburden. Correction factor for overburden can be estimated from Equation (16).

$$
\begin{aligned}
f & =1+\frac{(H-320)}{800} \geq 1 \\
& =1+\frac{(70-320)}{800}=0.69
\end{aligned}
$$

where $H$ is the height of overburden above crown in metres

Singh et al. [16] suggested an empirical approach (Equation (17)) based on case histories and by collecting Barton et al. [5] " $Q$ " data and overburden $(\mathrm{H})$ for the estimation of non-squeezing ground condition. Minimum $Q$-value is used for the estimation of ground squeezing condition. Above additional surge pool cavern maximum cover is $70 \mathrm{~m}$ hence ground condition is non-squeezing. The required support pressure for crown is be varying from $7.89 \mathrm{t} / \mathrm{m}^{2}$ to $12.43 \mathrm{t} / \mathrm{m}^{2}$ and for wall $4.61 \mathrm{t} / \mathrm{m}^{2}$ to $9.16 \mathrm{t} / \mathrm{m}^{2}$ (Table 9).

$$
\begin{aligned}
& H<350 Q^{1 / 3} \\
& 70<350 \times 4.17^{1 / 3}=563
\end{aligned}
$$

\section{Design of Supports}

As per hydraulic design, the additional surge pool is having an excavated width of $20.20 \mathrm{~m}$ and length $200 \mathrm{~m}$. The bottom level of surge pool is kept at EL 181.50 $\mathrm{m}$ and crown level is kept at EL $250.25 \mathrm{~m}$. The maximum upsurge level of surge 
Table 9. Support pressure for the roof and walls.

\begin{tabular}{|c|c|c|c|c|c|c|c|c|c|}
\hline $\begin{array}{l}\text { Sr. } \\
\text { No. }\end{array}$ & $\begin{array}{l}\text { Chainage } \\
(\mathrm{m})\end{array}$ & $\begin{array}{l}Q \text {-value } \\
\text { for roof }\end{array}$ & $\begin{array}{l}Q \text {-value } \\
\text { for wall }\end{array}$ & $\begin{array}{l}\text { Joint roughness } \\
\text { number for } \\
\text { crown \& wall }\end{array}$ & $\begin{array}{l}\text { Joint alteration } \\
\text { number for } \\
\text { crown \& wall }\end{array}$ & $\begin{array}{c}\text { Ultimate roof } \\
\text { support pressure } \\
\left(\mathrm{kg} / \mathrm{cm}^{2}\right)\end{array}$ & $\begin{array}{c}\text { Ultimate wall } \\
\text { support pressure } \\
\left(\mathrm{kg} / \mathrm{cm}^{2}\right)\end{array}$ & $J_{r} / J_{a}$ & $\begin{array}{c}\text { Friction Angle } \\
\varphi_{j}=\tan ^{-1}\left(J_{r} / J_{a}\right)\end{array}$ \\
\hline 1 & $0-5$ & 10.22 & 51.10 & 1.0 & 1.0 & 0.922 & 0.539 & 1.0 & 45 \\
\hline 2 & $\begin{array}{c}5-10 \\
200-205\end{array}$ & 16.33 & 81.65 & 1.0 & 1.0 & 0.789 & 0.461 & 1.0 & 45 \\
\hline 3 & $10-20$ & 12.25 & 61.25 & 1.0 & 2.0 & 0.868 & 0.508 & 0.5 & 27 \\
\hline 4 & $\begin{array}{c}20-30, \\
65-70, \\
75-80 \\
130-135 \\
160-165, \\
210-220\end{array}$ & 7.92 & 19.80 & 1.0 & 2.0 & 1.004 & 0.740 & 0.5 & 27 \\
\hline 5 & $\begin{array}{l}30-35 \\
50-55\end{array}$ & 15.33 & 76.65 & 1.0 & 1.0 & 0.805 & 0.471 & 1.0 & 45 \\
\hline 6 & $35-40$ & 14.67 & 73.35 & 1.0 & 1.0 & 0.817 & 0.478 & 1.0 & 45 \\
\hline 7 & $\begin{array}{c}40-45 \\
195-200 \\
205-210\end{array}$ & 15.83 & 79.15 & 1.0 & 1.0 & 0.797 & 0.466 & 1.0 & 45 \\
\hline 8 & $45-50$ & 11.88 & 59.40 & 1.0 & 2.0 & 0.877 & 0.513 & 0.5 & 27 \\
\hline 9 & $55-60$ & 10.89 & 54.45 & 1.0 & 1.0 & 0.903 & 0.528 & 1.0 & 45 \\
\hline 10 & $60-65$ & 12.38 & 61.90 & 1.0 & 2.0 & 0.865 & 0.506 & 0.5 & 27 \\
\hline 11 & $\begin{array}{l}70-75 \\
80-85\end{array}$ & 7.67 & 19.17 & 1.0 & 2.0 & 1.014 & 0.748 & 0.5 & 27 \\
\hline 12 & $85-90$ & 4.89 & 12.22 & 1.0 & 2.0 & 1.178 & 0.869 & 0.5 & 27 \\
\hline 13 & $\begin{array}{c}90-95 \\
155-160 \\
165-175, \\
185-195\end{array}$ & 7.33 & 18.32 & 1.0 & 2.0 & 1.030 & 0.759 & 0.5 & 27 \\
\hline 14 & $95-100$ & 4.72 & 11.80 & 1.0 & 2.0 & 1.192 & 0.879 & 0.5 & 27 \\
\hline 15 & $\begin{array}{c}100-105 \\
125-130 \\
175-180\end{array}$ & 6.83 & 17.07 & 1.0 & 2.0 & 1.054 & 0.777 & 0.5 & 27 \\
\hline 16 & $105-110$ & 12.50 & 62.50 & 1.0 & 1.0 & 0.862 & 0.504 & 1.0 & 45 \\
\hline 17 & $110-115$ & 13.67 & 68.35 & 1.0 & 1.0 & 0.837 & 0.489 & 1.0 & 45 \\
\hline 18 & $115-120$ & 14.17 & 70.85 & 1.0 & 1.0 & 0.827 & 0.484 & 1.0 & 45 \\
\hline 19 & $120-125$ & 10.56 & 52.80 & 1.0 & 1.0 & 0.912 & 0.533 & 1.0 & 45 \\
\hline 20 & $135-155$ & 4.56 & 11.40 & 1.0 & 2.0 & 1.206 & 0.889 & 0.5 & 27 \\
\hline 21 & $180-185$ & 4.17 & 10.42 & 1.0 & 2.0 & 1.243 & 0.916 & 0.5 & 27 \\
\hline
\end{tabular}

pool works out to EL $239.90 \mathrm{~m}$ and minimum downsurge level works out to EL $214.80 \mathrm{~m}$. As per design $300 \mathrm{~mm}$ thick concrete lined is proposed at the invert level of surge pool. For structural stability of surge pool segment above concrete lined portion, rock support arrangements were recommended based on rock 
mass quality $Q$ and site geological condition. The objective of reinforcement system was to minimize deformations induced by the dead weight of loosened rock mass, as well as those induced by stress redistribution in the rock surrounding an excavation [18].

The rock mass quality $Q$ was developed after making a consistent relationship between $Q$, the excavation dimension, and the support actually used. The permanent support estimate is based on the rock mass quality $Q$, the support pressure, and the equivalent dimension and purpose of the excavation. The Equivalent Dimension (De) is applied by dividing the span or height ( $\mathrm{m}$ ) by the Excavation Support Ratio (ESR). The ESR for surge pool cavity as given in the ESR updated classification standard of NMT $Q$-system is applied to 1.0 [19].

Bolt lengths depend on the dimensions of excavations and the length of rock bolts can be estimated from the excavation span (B) or height $(\mathrm{H})$ and the excavation support ratio (ESR) [5] [20]. Lengths used in the roof arch are usually related to the span (Equation (18)), while lengths used in the walls are usually related to the height of excavations (Equation (19)).

$$
\begin{aligned}
& L_{\text {roof }}=2+\frac{0.15 B}{\mathrm{ESR}} \\
& L_{\text {walls }}=2+\frac{0.15 H}{\mathrm{ESR}}
\end{aligned}
$$

where, $L_{\text {roof/walls }}$ are bolt length in metres for roof and walls, $B$ is span in metres, $H$ is excavation height in metres and ESR is the excavation support ratio.

By applying the above formula, the length of rock bolt for the crown and walls is calculated to be $5.03 \mathrm{~m}$ and $10.78 \mathrm{~m}$ respectively. The value of NMT $Q$-system chart proposed is $5.0-6.0 \mathrm{~m}$ and $11.50-13.0 \mathrm{~m}$ for crown and surge pit walls respectively.

The Norwegian Institute for Rock Blasting Technique has proposed a formula to estimate the length of the bolts in the central section of the opening [18]. By applying this, the length of rock bolt for crown of pump house is calculated to be $5.12 \mathrm{~m}$ (Equation (20)).

$$
L=1.40+0.184 B
$$

where $B$ is the span of the opening in metres

The thickness of steel fibre reinforced shotcrete can be estimated as per equation (Equation (21)) from the ultimate support pressure $\left(P_{\text {roof }}\right)$ and size of opening ( $B$ ) [21] [22] [23]. The thickness of SFRS for crown and surge pool walls is calculated from the average $Q$-value to be $104 \mathrm{~mm}$ and $222 \mathrm{~mm}$ respectively. The value of NMT $Q$-system chart proposed is $80-100 \mathrm{~mm}$ and $120-140$ $\mathrm{mm}$ for crown and surge pit walls respectively.

$$
t_{f s c}=\frac{P_{\text {roof }} \times B \times F_{f s c}}{2 q_{f s c}}
$$

where, $t_{f s c}$ is thickness of SFRS lining, $P_{\text {roof }}$ is ultimate roof/wall support pressure, $B$ is size of opening, $F_{f s c}$ is mobilization factor for shotcrete $(0.6 \pm$ 
0.05) and $q_{f s c}$ is shear strength of fibre reinforced shotcrete $\left(550 \mathrm{t} / \mathrm{m}^{2}\right)$

The rock support arrangement includes steel fibre reinforced shotcrete, rock bolt, grouting and drainage holes provisions (Figure 2, Table 10). On the basis of geological mapping of the heading portion additional rock bolts of $6 \mathrm{~m}$ length is recommended at the centre of each grid between Ch $125 \mathrm{~m}$ and Ch $180 \mathrm{~m} \mathrm{(3 \textrm {m }}$ on either side of centre line) and at Ch. $193 \mathrm{~m}$ ( $3 \mathrm{~m}$ on either side of centre line).

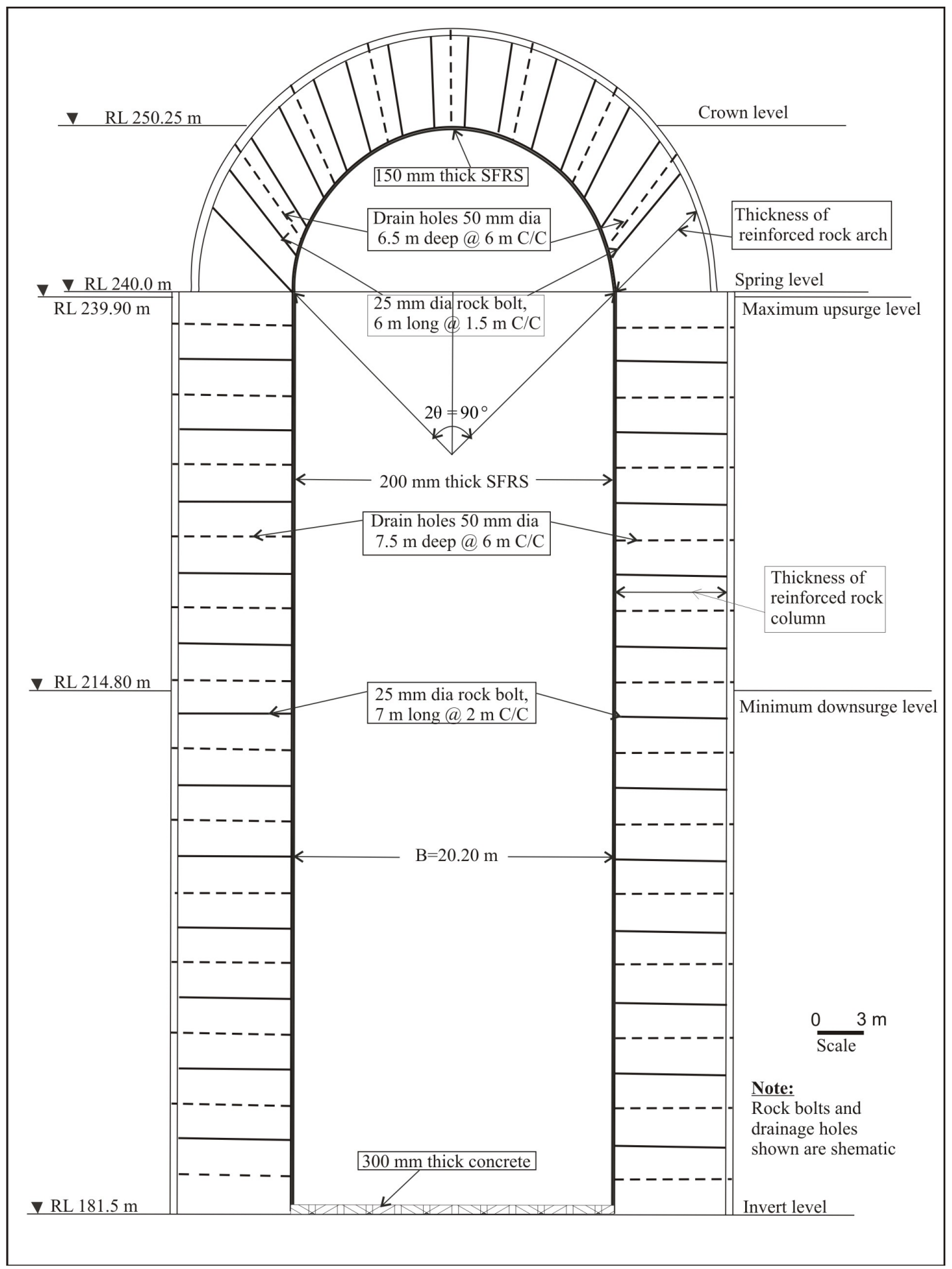

Figure 2. Support system of the surge pool cavern. 
Table 10. Details of rock support arrangement.

\begin{tabular}{|c|c|c|c|c|c|}
\hline \multirow{2}{*}{$\begin{array}{l}\text { Surge } \\
\text { pool EL } \\
(\mathrm{m})\end{array}$} & \multicolumn{3}{|c|}{ Required Support } & \multirow[b]{2}{*}{ Grouting } & \multirow[b]{2}{*}{ Drainage Arrangement } \\
\hline & Rock Bolts & $\begin{array}{l}\text { Rock bolt } \\
\text { spacing }\end{array}$ & Shotcrete & & \\
\hline Crown & $\begin{array}{l}6 \mathrm{~m} \text { long, } 25 \mathrm{~mm} \text { diameter } \\
\text { resin end anchored cement } \\
\text { grouted rock bolts (Fe415) }\end{array}$ & $\begin{array}{l}1500 \mathrm{~mm} \mathrm{c} / \mathrm{c} \\
\text { (staggered) }\end{array}$ & $\begin{array}{l}150 \mathrm{~mm} \text { thick steel } \\
\text { fibre reinforced } \\
\text { shotcrete }\end{array}$ & $\begin{array}{l}\text { Up to } 6.5 \mathrm{~m} \text { and spacing } \\
\text { should be decided on } \\
\text { the trial basis }\end{array}$ & $\begin{array}{l}6.5 \mathrm{~m} \text { long } 50 \mathrm{~mm} \text { diameter drain } \\
\text { hole @ } 6000 \mathrm{~mm} \mathrm{c} / \mathrm{c}\end{array}$ \\
\hline Side walls & $\begin{array}{l}7 \mathrm{~m} \text { long, } 25 \mathrm{~mm} \text { diameter } \\
\text { resin end anchored cement } \\
\text { grouted rock bolts (Fe415) }\end{array}$ & $\begin{array}{l}2000 \mathrm{~mm} \mathrm{c} / \mathrm{c} \\
\text { (staggered) }\end{array}$ & $\begin{array}{l}200 \mathrm{~mm} \text { thick steel } \\
\text { fibre reinforced } \\
\text { shotcrete }\end{array}$ & $\begin{array}{l}\text { Up to } 7.5 \mathrm{~m} \text { and spacing } \\
\text { should be decided on } \\
\text { the trial basis }\end{array}$ & $\begin{array}{l}7.5 \mathrm{~m} \text { long } 50 \mathrm{~mm} \text { diameter drain } \\
\text { hole @ } 6000 \mathrm{~mm} \mathrm{c} / \mathrm{c} \text { up to } \\
\text { maximum surge level }\end{array}$ \\
\hline
\end{tabular}

Note: Where additional support capacity is required to support local areas of weaker rock, bolts placed at the centre of each grid square will suffice.

\section{Estimation of Support System Capacity}

The capacity of support system consisting of SFRS, rock bolt and grouted arch/ rock column for surge pool cavern is determine using the integrated approach given by Singh et al. [21], Singh and Goel [22] and IS: 15026 [23]. The total support pressure $\left(u+p_{\text {roof/wall }}\right)$ will be equal to the sum of capacities of support system (Equation (22)).

$$
u+p_{\text {roof } / \text { wall }}=p_{\text {sc }}+p_{\text {bolt }}+p_{g t}
$$

where,

$$
\begin{aligned}
& u=\text { seepage water pressure }=0.0 \mathrm{t} / \mathrm{m}^{2} . \\
& \left.p_{\text {roof }}=\text { roof support pressure (varying from } 7.89 \text { to } 12.43 \mathrm{t} / \mathrm{m}^{2}\right) . \\
& \left.p_{\text {wall }}=\text { wall support pressure (varying from } 4.61 \text { to } 9.16 \mathrm{t} / \mathrm{m}^{2}\right) . \\
& p_{s c}=\text { capacity of SFRS }\left(\mathrm{t} / \mathrm{m}^{2}\right) . \\
& p_{\text {bolt }}=\text { capacity of rock bolts }\left(\mathrm{t} / \mathrm{m}^{2}\right) . \\
& p_{g t}=\text { capacity of grouted arch } / \text { rock column }\left(\mathrm{t} / \mathrm{m}^{2}\right) .
\end{aligned}
$$

It is assumed that the fibre reinforced shotcrete is intimately in contact with the rock mass and having the tendency to fail by shearing. Before putting shotcrete, the exposed surface should be properly cleaned and scaled because the strong bond between shotcrete and rock mass is the key to success in stabilizing a cavern The capacity of SFRS as estimated (Equation (23)) for roof and walls is $13.61 \mathrm{t} / \mathrm{m}^{2}$ and $6.27 \mathrm{t} / \mathrm{m}^{2}$ respectively.

$$
p_{s c}=\frac{2 q_{f s c} \times t_{f s c}}{B F_{f s c}}
$$

where,

$$
\begin{aligned}
& p_{s c}=\text { capacity of SFRS lining }\left(\mathrm{t} / \mathrm{m}^{2}\right) . \\
& q_{f s c}=\text { shear strength of SFRS }\left(550 \mathrm{t} / \mathrm{m}^{2}\right) . \\
& t_{f s c}=\text { thickness of SFRS }(0.150 \mathrm{~m} \text { for roof; } 0.200 \mathrm{~m} \text { for walls }) . \\
& B=\text { size of opening }(20.20 \mathrm{~m} \text { for roof; } 58.50 \mathrm{~m} \text { for pump pit wall }) . \\
& F_{f s c}=\text { mobilization factor for shotcrete }(0.6 \pm 0.05 \text { for higher for cavern }) .
\end{aligned}
$$

The capacity of rock bolt is estimated (Equation (24)) and the minimum capacity for roof and surge pit walls calculated is $1.577 \mathrm{t} / \mathrm{m}^{2}$, and $0.349 \mathrm{t} / \mathrm{m}^{2}$ respectively. 


$$
p_{\text {bolt }}=\frac{2 q_{c r m} \times l^{\prime} \sin \theta}{B F_{s}}
$$

where,

$$
p_{\text {bolt }}=\text { capacity of rock bolt }\left(\mathrm{t} / \mathrm{m}^{2}\right)
$$

$q_{c r m}=$ UCS of reinforced rock mass (18.38 and $41.09 \mathrm{t} / \mathrm{m}^{2}$ for roof and 10.34 and $23.11 \mathrm{t} / \mathrm{m}^{2}$ for walls) (Equation 25)

$l^{\prime}=$ thickness of reinforced rock arch/rock column $(5.125 \mathrm{~m}$ for roof and $4.00 \mathrm{~m}$ for walls) (Equations ((26) and (27)))

$$
\theta=\theta^{\circ} ; \operatorname{Sin} \theta=0.707
$$

$B$ = size of opening (20.20 m-roof; $58.50 \mathrm{~m}$-pump pit wall)

$F_{\mathrm{s}}=$ mobilization factor for rock bolts

Singh et al. [21] proposed mobilization factors after back analysis of Barton et al. [5] support systems case studies. From 120 case histories, Thakur [24] confirmed these design criteria. For rock bolt mobilization factors $\left(F_{s}\right)$ are calculated from Equations 28 and 29 for roof and walls respectively. For roof $F_{s}$ values are varying from 3.996 to 4.181 while for walls values are ranging between 3.787 and 4.056 .

$$
\begin{gathered}
q_{c r m}=\left[\frac{P_{\text {bolt }}}{S_{\text {bolt }}^{2}}-u\right] \times\left[\frac{\left(1+\sin \varphi_{j}\right)}{1-\sin \varphi_{j}}\right] \\
\tan \varphi_{j}=\frac{J_{r}}{J_{a}} \\
l_{\text {arch }}^{\prime}=l-\frac{\text { FAL }}{2}-\frac{S_{\text {bolt }}}{4}+S_{\text {rock }} \\
l_{\text {column }}^{\prime}=l-\frac{\text { FAL }}{2}-\frac{S_{\text {bolt }}}{4}+S_{\text {rock }}-d \\
F_{s}=3.25 \times p_{\text {roof }}^{0.1} \\
F_{s}=3.25 \times p_{\text {Wall }}^{0.1}
\end{gathered}
$$

where,

$l$ = length of bolt ( $6 \mathrm{~m}$ for roof and $7 \mathrm{~m}$ for walls).

FAL = fixed anchor length $(2.5 \mathrm{~m})$.

$S_{\text {bolt }}=$ spacing of bolt $(1.5 \mathrm{~m}$ for roof and $2 \mathrm{~m}$ for walls).

$S_{\text {rock }}=$ average spacing of joints $(0.750 \mathrm{~m})$.

$d=$ depth of damaged rock due to blasting in walls (av. $2.0 \mathrm{~m}$ ).

$u=$ seepage pressure in the rock mass $\left(0.00 \mathrm{t} / \mathrm{m}^{2}\right)$.

$J_{r}=$ joint roughness number.

$J_{a}=$ joint alteration number.

$p_{\text {roof }}=$ roof support pressure (varying from 7.89 to $12.43 \mathrm{t} / \mathrm{m}^{2}$ ).

$p_{\text {wall }}=$ wall support pressure (varying from 4.61 to $9.16 \mathrm{t} / \mathrm{m}^{2}$ ).

The capacity of grouted rock arch/rock column is calculated by the Equation 30. The minimum grouted arch/rock column capacity for roof and surge pit walls calculated is $2.650 \mathrm{t} / \mathrm{m}^{2}$ and $0.492 \mathrm{t} / \mathrm{m}^{2}$ respectively. 


$$
p_{g t}=\frac{2 q_{g t} \times l_{g t}}{B F_{g t}}
$$

where,

$p_{g t}=$ capacity of grouted arch/rock column $\left(\mathrm{t} / \mathrm{m}^{2}\right)$.

$q_{g t}=$ UCS of grouted rock mass (18.38 and $41.09 \mathrm{t} / \mathrm{m}^{2}$ for roof and 10.34 and $23.11 \mathrm{t} / \mathrm{m}^{2}$ for walls).

$l_{g t}=$ thickness of grouted arch/rock column $(6.5 \mathrm{~m}$ for roof and $7.5 \mathrm{~m}$ for walls).

$B$ = size of opening (20.20 m-roof; $58.50 \mathrm{~m}$-pump pit wall).

$F_{s}=$ mobilization factor for grouted arch/rock column.

For grouted arch/rock column mobilization factors $\left(F_{g t}\right)$ are calculated from Equations 31 and 32 for roof and walls respectively. For roof $F_{g t}$ values are varying from 3.932 to 4.610 while for walls values are ranging between 4.376 and 5.564. Total capacity of support system for roof and walls calculated at different Chainage is given in Table 11.

Table 11. Capacity of support system for the roof and walls.

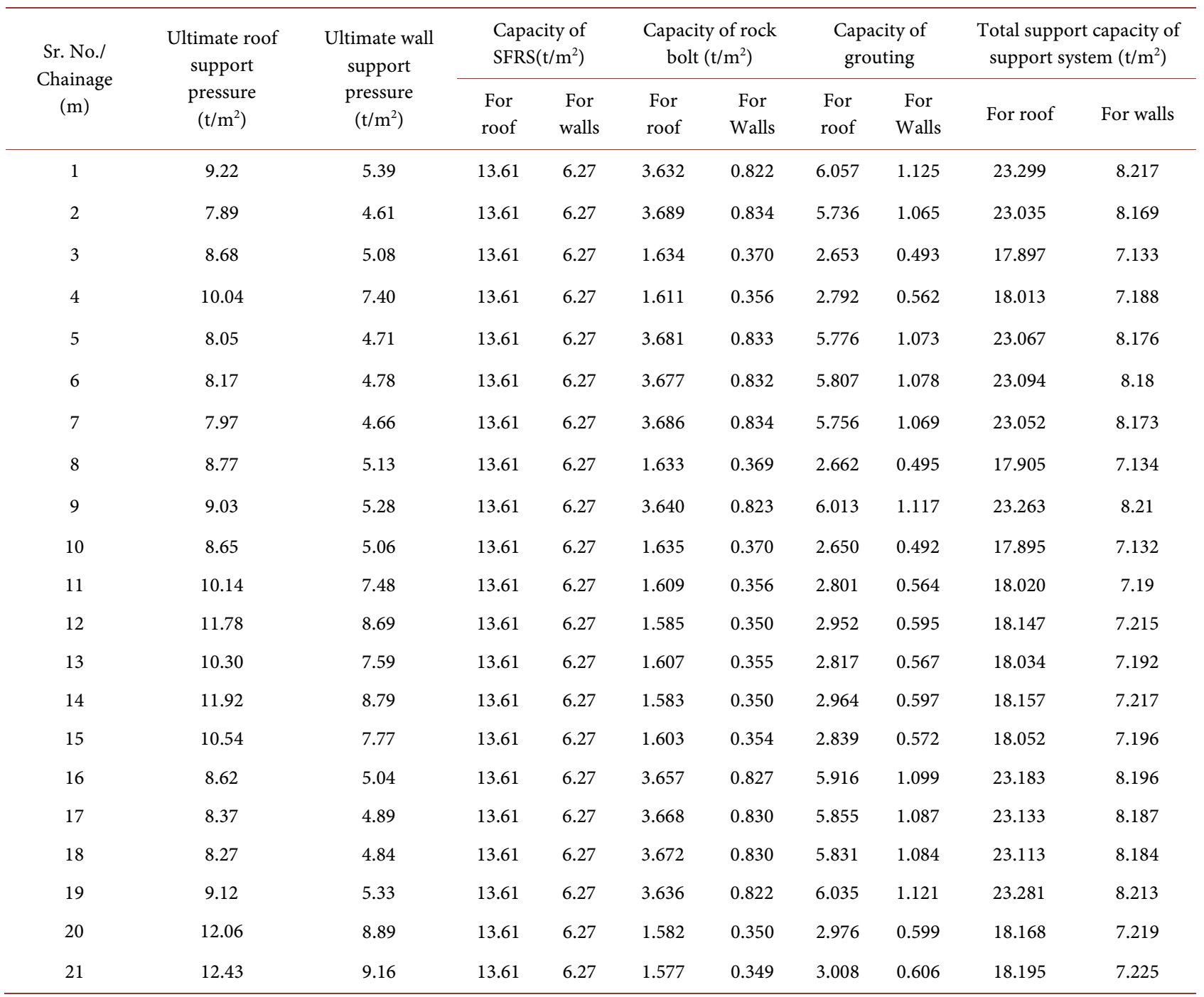




$$
\begin{aligned}
& F_{g t}=9.50 \times p_{\text {roof }}^{-0.35} \\
& F_{g t}=9.50 \times p_{\text {wall }}^{-0.35}
\end{aligned}
$$

\section{Conclusion}

3D geologic mapping of heading portion using pilot and side slashing is very important for large cavern for predicting geologic conditions in benching down up to invert level. Geologic logging data were used for rock mass characterization and for support pressure estimation. Logging data were also used in planning tunnel support system and selecting best location and inclination of supplemental rock bolt. Support design empirical approaches are used. Empirical approaches are the best way for support design which is backed by a systematic approach to rock mass classification and providing a quantitative assessment of rock mass conditions. For structural stability, the rock support arrangement includes steel fibre reinforced shotcrete (SFRS), rock bolt, grouting and drainage hole provisions. Geologic logging data will also be very useful for choosing strategic locations for various types of instrumentation to study tunnel behavior. This cavern will be one of the biggest caverns in the world, so it is recommended that the support requirements may be re-evaluated in the light of the rock mass conditions revealed during the benching down of the cavern and the instrumentation data.

\section{Acknowledgements}

This paper is a part of sponsored project by M/s MEIL, so we sincerely thank the management of MEIL for the same. Authors are thankful to Director NIRM for the permission to send the manuscript for publication, encouragement and technical guidance.

\section{References}

[1] Bieniawski, Z.T. (1989) Engineering Rock Mass Classification. John Willey and Sons, New York, $251 \mathrm{p}$.

[2] Ramam, P.K. and Murty, V.N. (2012) Geology of Andhra Pradesh. Geological Society of India, Bengaluru, $244 \mathrm{p}$.

[3] Prakash, D. and Sharma, I.N. (2011) Metamorphic Evolution of Karimnagar granulite Terrane, Eastern Dharwar Craton, South India. Geological Magazine, 48, 112 132. https://doi.org/10.1017/S0016756810000488

[4] ISRM (1981) Suggested Methods for the Rock Characterization, Testing and Monitoring. ISRM Commission on Testing Methods, Pergamon Press, Oxford.

[5] Barton, N., Lien, R. and Lunde, J. (1974) Engineering Classification of Rock Masses for the Design of Tunnel Support. Rock Mechanics, 6, 189-236.

https://doi.org/10.1007/BF01239496

[6] Grimstad, E. and Barton, N. (1993) Updating of the Q-System for NMT. Proceedings of the International Symposium on Sprayed Concrete, Fagernes, 22-26 October 1993, 46-66.

[7] Grimstad, E., Kankes, K., Bhasin, R., Magnussen, A. and Kaynia, A. (2002) Rock Mass Quality Q Used in Designing Reinforced Ribs of Sprayed Concrete and Energy 
Absorption. Proceedings of International Symposium on Sprayed Concrete, Davos, 22-26 September 2002, 134-142.

[8] Bieniawski, Z.T. (1973) Engineering Classification of Jointed Rock Masses. Transaction of the South African Institution of Civil Engineers, 15, 335-344.

[9] Bieniawski, Z.T. (1979) The Geomechanics Classification in Rock Engineering Application. Proceedings 4th International Congress on Rock Mechanics, Montreux, 2-8 September 1979, Vol. 2, 41-48.

[10] Gonzalez de Vallejo, L.I. (1983) A New Rock Classification System for Underground Assessment Using Surface Data. Proceedings International Symposium on Engineering Geology and Underground Construction, Lisbon, 12 September 1983, 85-94.

[11] Nakao, K., Iihoshi, S. and Koyama, S. (1983) Statistical Reconsiderations on the Parameters for Geomechanics Classification. Proceeding 5th International Congress on Rock Mechanics, Melbourne, 10-15 April 1983, Vol. 1, B13-B16.

[12] Naithani, A.K. (2007) RMR-A System for Characterizing Rock Mass Classification: A Case Study from Garhwal Himalaya, Uttarakhand. Journal Geological Society of India, 70, 627-640.

[13] Hoek, E. and Brown, E.T. (1997) Practical Estimates of Rock Mass Strength. International Journal Rock Mechanics Mining Science, 34, 1165-1186.

[14] Hoek, E. and Brown, E.T. (1980) Underground Excavations in Rock. London Institution of Mining and Metallurgy, London, $527 \mathrm{p}$.

[15] Maybee, W.G. and Martin, C.D. (2000) The Strength of Hard-Rock Pillars. International Journal of Rock Mechanics and Mining, 37, 1239-1246.

[16] Singh, B., Jethwa, J.L., Dube, A.K. and Singh, B. (1992) Correlation between Observed Support Pressure and Rock Mass Quality. Tunnelling and Underground Space Technology, 7, 59-74.

[17] IS 13365 (1992) Quantitative Classification Systems of Rock Mass-Guidelines, Part-2, Rock Mass Quality for Prediction of Support Pressure in Underground Openings. Bureau of Indian Standards, New Delhi, 8 p.

[18] Stillborg, B. (1994) Professional Users Handbook for Rock Bolting. Trans Tech Publication, Aedermannsdorf, $164 \mathrm{p}$.

[19] NGI (2013) Using the Q-System-Rock Mass Classification and Support Design. NGI Publication, Oslo, $54 \mathrm{p}$.

[20] Barton, N., Loset, F., Lien, R. and Lunde, J. (1980) Application of the Q-System in Design Decisions Concerning Dimensions and Appropriate Support for Underground Installations. International Conference on Sub-Surface Space, Rock Store, Stockholm, 1980, Vol. 2, 553-561.

[21] Singh, B., Viladkar, M.N. and Samadhiya, N.K. (1995) A Semi-Empirical Method of the Design of Support Systems in Underground Openings. Tunnelling and Underground Space Technology, 3, 375-383.

[22] Singh, B. and Goel, R.K. (2011) Engineering Rock Mass Classification. Elsevier Inc. Publication, Amsterdam, 364 p.

[23] IS 15026 (2002) Tunnelling Methods in Rock Masses-Guidelines. Bureau of Indian Standards, New Delhi, 26 p.

[24] Thakur, B. (1995) Semi-Empirical Method for Design of Supports in Underground Excavations. ME Thesis, IIT Roorkee, Roorkee. 
Submit or recommend next manuscript to SCIRP and we will provide best service for you:

Accepting pre-submission inquiries through Email, Facebook, LinkedIn, Twitter, etc. A wide selection of journals (inclusive of 9 subjects, more than 200 journals)

Providing 24-hour high-quality service

User-friendly online submission system

Fair and swift peer-review system

Efficient typesetting and proofreading procedure

Display of the result of downloads and visits, as well as the number of cited articles Maximum dissemination of your research work

Submit your manuscript at: http://papersubmission.scirp.org/

Or contact gm@scirp.org 